\title{
Androgen Receptor Could Be a Potential Therapeutic Target in Patients with Advanced Hepatocellular Carcinoma
}

\author{
Tatsuo Kanda ${ }^{1, *}$, Koji Takahashi ${ }^{1}$, Masato Nakamura ${ }^{1}$, Shingo Nakamoto ${ }^{1}$, Shuang Wu ${ }^{1}$, \\ Yuki Haga ${ }^{1}$, Reina Sasaki ${ }^{1}$, Xia Jiang ${ }^{1,2}$ and Osamu Yokosuka ${ }^{1}$ \\ 1 Department of Gastroenterology and Nephrology, Chiba University, Graduate School of Medicine, \\ 1-8-1 Inohana, Chiba 260-8670, Japan; koji517@gmail.com (K.T.); nkmr.chiba@gmail.com (M.N.); \\ nakamotoer@yahoo.co.jp (S.N.); gosyou100@yahoo.co.jp (S.W.); hagayuki@gmail.com (Y.H.); \\ reina_sasaki_0925@yahoo.co.jp (R.S.); jxia925@yahoo.co.jp (X.J.); yokosukao@faculty.chiba-u.jp (O.Y.) \\ 2 Department of General Surgery, The First Hospital of Hebei Medical University, Donggang Road No. 89, \\ Shijiazhuang 050031, China \\ * Correspondence: kandat2t@yahoo.co.jp; Tel.: +81-43-226-2086
}

Academic Editor: Emmanuel S. Antonarakis

Received: 27 February 2017; Accepted: 3 May 2017; Published: 5 May 2017

\begin{abstract}
Hepatocellular carcinoma (HCC) is a male-dominant disease with poor prognosis. Sorafenib is the only approved systemic chemotherapeutic drug for patients with advanced HCC. Previous studies have shown that androgen and androgen receptor (AR) are involved in human hepatocarcinogenesis and the development of HCC. Here, we discuss the recent data on AR and HCC, and the combination of sorafenib and inhibitors of AR for advanced-HCC patients. Androgen-dependent and androgen-independent AR activation exist in human hepatocarcinogenesis. AR could directly control hepatocarcinogenesis and regulate the innate immune system to influence HCC progression. Combination of sorafenib with AR inhibitors might represent a potential treatment for patients with advanced HCC.
\end{abstract}

Keywords: androgen receptor; hepatocellular carcinoma; sorafenib

\section{Introduction}

Hepatocellular carcinoma (HCC) is one of the poor-prognosis cancers [1,2]. In Japan, HCC is the major cancer among primary liver cancers, which have 5- and 10-year survival rates of 34\% and 16\%, respectively [3]. HCC mostly occurs in patients with cirrhosis. It is not easy to cure HCC by surgical resection other than liver transplantation [4]. In patients with advanced HCC, sorafenib is the only approved systemic chemotherapeutic drug, and new treatment options are eagerly awaited [1].

To surpass the treatment with sorafenib alone for advanced HCC, new treatments have been developed in recent years $[2,5,6]$. Histone deacetylase inhibitor resminostat plus sorafenib was safe and showed early signs of efficacy for advanced HCC patients progressing on sorafenib-only treatment [5]. Sorafenib plus hepatic arterial infusion chemotherapy with cisplatin achieved favorable overall survival when compared with sorafenib alone for advanced HCC patients [6]. Regorafenib was also shown to provide survival benefit in advanced HCC patients progressing on sorafenib treatment [2].

HCC is one of the male-dominant cancers [7]. We and others have reported that male sex hormone androgen and androgen receptor (AR) are involved in human hepatocarcinogenesis and the development of HCC [8-12]. AR antagonists such as flutamide and bicalutamide have been used for prostate cancer for many decades, and new AR antagonists are also under development [13]. Herein, AR and HCC will be discussed. We also describe the combination treatment of sorafenib and inhibitors of AR for patients with advanced HCC. 


\section{AR and AR Signaling}

Androgens act through AR, a 110-kDa ligand-inducible nuclear receptor (Figure 1A) [14]. The classical steroid receptors such as AR, estrogen receptor, progesterone receptor, glucocorticoid receptor and mineral corticoid receptor are grouped as type 1 nuclear receptors. AR has four functional domains: $\mathrm{NH}_{2}$-terminal transactivation domain, DNA-binding domain (DBD), hinge region and ligand-binding domain (LBD).

AR regulates the expression of target genes that have androgen response elements (AREs) (Figure 1A) [14,15]. AREs exist in the promoter region of vascular endothelial growth factor (VEGF) [8] and glucose-regulated protein $78 \mathrm{kDa}$ (GRP78) [9], and they play a role in the growth of human hepatocytes. Transforming growth factor, beta 1 (TGF- $\beta 1$ ) transcription is also activated by androgen and AR complex in hepatocytes [16,17]. This transcriptional activation function of AR is important in the normal sexual development of the male gender as well as the progression of cancer $[8,14,18]$.

AR co-regulators also influence a number of functional properties of AR, including ligand selectivity and DNA binding capacity [14]. Oncogenes such as erb-b2 receptor tyrosine kinase 2 (ERBB2) and HRas proto-oncogene, GTPase (HRAS) increase mitogen-activated protein kinase signaling, which can cause ligand-independent activation of AR (Figure 1B) $[19,20]$. There is a cross-talk mechanism between growth factor signaling and androgen in prostate development, physiology, and cancer [20]. Ligand-independent activation of AR pathways also plays a role in human HCC and pancreatic cancer progression $[8,21]$.

The activation of Src kinase is involved in the ligand-independent activation of AR [22]. Two UDP-glucuronosyltransferases (2B15 and 2B7) are also involved in inactivation of androgens, and may have a major role in persons that is null genotype of UGT2B17 [23]. Hepatitis B X (HBx) also augmented AR activity by enhancing the phosphorylation of AR through HBx-mediated activation of the c-Src kinase signaling pathway in human hepatocarcinogenesis [11,24].

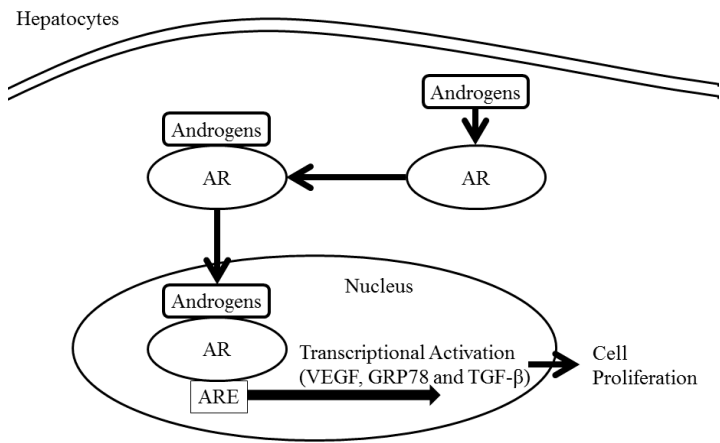

(A)

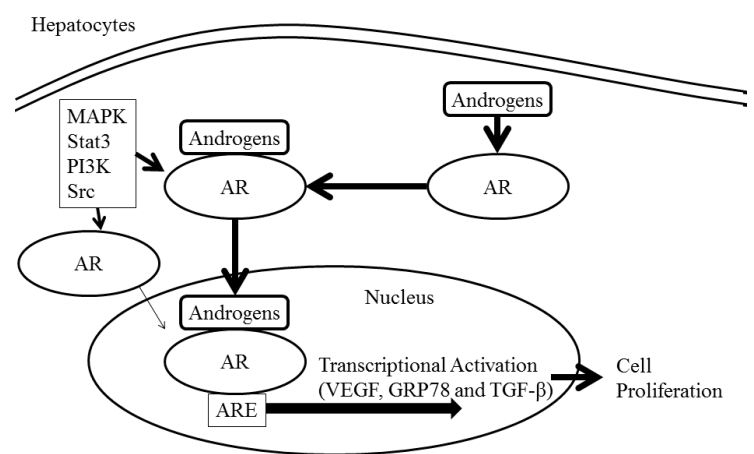

(B)

Figure 1. Androgen-dependent and androgen-independent androgen receptor (AR) activation in human hepatocarcinogenesis. (A) Androgen-dependent signaling. (B) Androgen-independent signaling. Phosphorylation of mitogen-activated protein kinase (MAPK), signal transducer and activator of transcription 3 (Stat3), AKT serine/threonine kinase 1 (Akt) and Proto-oncogene tyrosine-protein kinase (Src) activates AR. VEGF, vascular endothelial growth factor; GRP78, glucose-regulated protein $78 \mathrm{kDa}$; TGF- $\beta$, transforming growth factor, beta 1 ; PI3K, phosphatidylinositol-4,5-bisphosphate 3-kinase catalytic subunit alpha.

\section{AR and HCC}

Human HCC and normal liver express AR $[7,10,25]$. Hepatitis B virus (HBV) and hepatitis $\mathrm{C}$ virus (HCV) are two major causes of HCC. AR signaling is involved in human HCC associated with HBV and HCV [26]. AR signaling should be involved in hepatocarcinogenesis to some extent, irrespective of the cause of human and mouse HCC [27]. As androgen and AR-signaling are 
associated with the development of steatosis [28], AR may be associated with HCC that is related to non-alcoholic steatohepatitis.

Increased expression of variant transcripts from the AR gene (ARVs) has been shown to be involved in the development of castration-resistant prostate cancer [29]. The expression of ARVs was observed in the liver and may be involved in hepatocarcinogenesis [30]. AR variants may also lead to resistance to HCC antiandrogen therapy in the liver.

\section{AR and Sorafenib in the Treatment of HCC (Table 1)}

At present, sorafenib is the only approved drug for systemic chemotherapy of HCC. We observed that sorafenib-induced apoptosis was enhanced by the inhibition of AR and GRP78 in human hepatoma cell lines [9]. Sorafenib also inhibits AR activation induced by HBx in vitro and in vivo [31]. Of interest, this AR-targeting ability of sorafenib was not mediated by its well-known kinase inhibitory activity; however, this ability of sorafenib was achieved by enhancing the activity of K-box region and MADS-box transcription factor family protein (SHP-1) tyrosine phosphatase [31]. There are contrary opinions concerning hepatic AR and the effect of sorafenib, namely that hepatic AR suppresses HCC metastasis through modulation of cell migration and anoikis [30,32,33]. Natural killer (NK) cells suppress HCC; and interleukin 12 (IL12A), one of the NK cell stimulatory factors, plays a role in the activation of NK cell function [34,35]. In NK cells, AR could suppress IL12A expression at the transcriptional level, resulting in repressing the efficacy of NK cell cytotoxicity against HCC [34]. Sorafenib treatment interacts with AR and enhances IL12A signals [34]. AR could regulate the innate immune system to influence HCC progression [34,36,37]. Although AR suppresses HCC metastasis at late stage $[28,32,33,37]$, androgen and the AR axis maintain and promote cancer cell stemness through activation of Nanog in HCC [38].

Table 1. Molecular targets during anti-cancer drug treatment for hepatocellular carcinoma (HCC) through androgen receptor (AR).

\begin{tabular}{cll}
\hline References & Targets & \multicolumn{1}{c}{ Effects of Anti-Cancer Drugs } \\
\hline Jiang et al. [9] & GRP78 & $\begin{array}{l}\text { Knockdown of GRP78 and AR enhances apoptosis induced by } \\
\text { sorafenib in human hepatoma cells. }\end{array}$ \\
\hline Wang et al. [31] & SHP-1 & $\begin{array}{l}\text { Sorafenib inhibited HBx-enhanced AR activity by activating } \\
\text { SHP-1 phosphatase in HBx-transgenic mice. }\end{array}$ \\
\hline Shi et al. [34] & IL12A & Sorafenib interacts with AR and enhances IL12A signals. \\
\hline Shi et al. [36] & ULBP2 & $\begin{array}{l}\text { By suppressing AR, cisplatin could up-regulate cytotoxicity of } \\
\text { NK cells to target HCC. }\end{array}$ \\
\hline Ma et al. [28] & p-p38, NFKB, MMP9 & Addition of sorafenib improved HCC survival of L-AR ${ }^{-/ y}$ mice. \\
\hline Xu et al. [33] & miR-367 & $\begin{array}{l}\text { Combining miR-367-3p with Sorafenib showed better efficacy of } \\
\text { suppressing HCC cell invasion by altering AR signals in vitro } \\
\text { and in vivo. }\end{array}$ \\
\hline
\end{tabular}

GRP78, glucose-regulated protein $78 \mathrm{kDa}$; SHP-1, K-box region and MADS-box transcription factor family protein; $\mathrm{HBx}$, hepatitis B x; IL12A, interleukin 12A; ULBP2, UL16-binding protein 2; p-p38, phosphorylation of p38 kinase; NF- $\mathrm{kB}$, nuclear factor kappa B; MMP9, matrix metalloproteinase 9.

\section{Conclusions}

We have already reviewed clinical trials targeting androgen in HCC [25]. However, the previous reports demonstrated that anti-androgen therapies did not show any survival benefits in advanced HCC patients $[39,40]$. That might be considered to be attributed by the lower expression of AR and androgen-independent AR activation mechanism in the advanced HCC. A recent review [13] described phase I/II clinical trials of the androgen antagonist enzalutamide with or without sorafenib for advanced HCC that are currently underway. Enzalutamide binds to the AR with greater relative affinity than the clinically used antiandrogen bicalutamide, reduces the efficiency of its nuclear translocation, and impairs both DNA binding to androgen response elements and recruitment of 
coactivators [41]. The combination of sorafenib and enzalutamide is a potentially new approach for the treatment of castration-resistant prostate cancer [42]. This combination may present a potential treatment for patients with advanced HCC. In prostatic cancer cells with downregulated AR expression by short interfering RNA, treatment with sorafenib increased apoptosis in an additive manner [43], suggesting that there might be a potential to use inhibitors of AR in HCC as an adjuvant therapy option for sorafenib-resistant HCC patients. Moreover, immune checkpoint inhibitors such as programmed cell death 1 (PD-1), programmed cell death ligand 1 (PD-L1), or cytotoxic T-lymphocyte-associated protein 4 (CTLA-4) are now undergoing clinical trials, and they may open new doors for the treatment of HCC [44]. In this new era, AR could control NK cell function and may be a more attractive target. In conclusion, recent advances regarding AR in HCC have been described. AR is an attractive target with or without anti-cancer drugs in HCC, one of the male dominant diseases.

Acknowledgments: We extended our thanks to Prof. Fumio Imazeki and Prof. Naoya Kato for helpful suggestions. This work was partly supported by grants from the Japan Agency for Medical Research and Development (AMED).

Author Contributions: Tatsuo Kanda, Koji Takahashi, Masato Nakamura, Shingo Nakamoto, Shuang Wu, Yuki Haga, Reina Sasaki, Xia Jiang and Osamu Yokosuka conceived, designed and wrote the paper.

Conflicts of Interest: Tatsuo Kanda received research grants from Merck Sharp and Dohme (MSD), Chugai Pharm and AbbVie. The founding sponsors had no role in the design of the study; in the collection, analyses, or interpretation of data; in the writing of the manuscript, and in the decision to publish the results. The other authors declare no conflict of interest.

\section{References}

1. Llovet, J.M.; Ricci, S.; Mazzaferro, V.; Hilgard, P.; Gane, E.; Blanc, J.F.; de Oliveira, A.C.; Santoro, A.; Raoul, J.L.; Forner, A.; et al. SHARP Investigators Study Group. Sorafenib in advanced hepatocellular carcinoma. N. Engl. J. Med. 2008, 359, 378-390. [CrossRef] [PubMed]

2. Bruix, J.; Qin, S.; Merle, P.; Granito, A.; Huang, Y.H.; Bodoky, G.; Pracht, M.; Yokosuka, O.; Rosmorduc, O.; Breder, V.; et al. RESORCE Investigators. Regorafenib for patients with hepatocellular carcinoma who progressed on sorafenib treatment (RESORCE): A randomised, double-blind, placebo-controlled, phase 3 trial. Lancet 2017, 389, 56-66. [CrossRef]

3. National Cancer Center. Center for Cancer Control and Information Services. Available online: http: //ganjoho.jp/reg_stat/statistics/stat/summary.html (accessed on 23 February 2017).

4. Kanda, T.; Ogasawara, S.; Chiba, T.; Haga, Y.; Omata, M.; Yokosuka, O. Current management of patients with hepatocellular carcinoma. World J. Hepatol. 2015, 7, 1913-1920. [CrossRef] [PubMed]

5. Bitzer, M.; Horger, M.; Giannini, E.G.; Ganten, T.M.; Wörns, M.A.; Siveke, J.T.; Dollinger, M.M.; Gerken, G.; Scheulen, M.E.; Wege, H.; et al. Resminostat plus sorafenib as second-line therapy of advanced hepatocellular carcinoma-The SHELTER study. J. Hepatol. 2016, 65, 280-288. [CrossRef] [PubMed]

6. Ikeda, M.; Shimizu, S.; Sato, T.; Morimoto, M.; Kojima, Y.; Inaba, Y.; Hagihara, A.; Kudo, M.; Nakamori, S.; Kaneko, S.; et al. Sorafenib plus hepatic arterial infusion chemotherapy with cisplatin versus sorafenib for advanced hepatocellular carcinoma: Randomized phase II trial. Ann. Oncol. 2016, 27, 2090-2096. [CrossRef] [PubMed]

7. Nagasue, N.; Yu, L.; Yukaya, H.; Kohno, H.; Nakamura, T. Androgen and oestrogen receptors in hepatocellular carcinoma and surrounding liver parenchyma: Impact on intrahepatic recurrence after hepatic resection. Br. J. Surg. 1995, 82, 542-547. [CrossRef] [PubMed]

8. Kanda, T.; Steele, R.; Ray, R.; Ray, R.B. Hepatitis C virus core protein augments androgen receptor-mediated signaling. J. Virol. 2008, 82, 11066-11072. [CrossRef] [PubMed]

9. Jiang, X.; Kanda, T.; Nakamoto, S.; Miyamura, T.; Wu, S.; Yokosuka, O. Involvement of androgen receptor and glucose-regulated protein $78 \mathrm{kDa}$ in human hepatocarcinogenesis. Exp. Cell Res. 2014, 323, 326-336. [CrossRef] [PubMed]

10. Kanda, T.; Jiang, X.; Yokosuka, O. Androgen receptor signaling in hepatocellular carcinoma and pancreatic cancers. World J. Gastroenterol. 2014, 20, 9229-9236. [PubMed]

11. Chiu, C.M.; Yeh, S.H.; Chen, P.J.; Kuo, T.J.; Chang, C.J.; Chen, P.J.; Yang, W.J.; Chen, D.S. Hepatitis B virus X protein enhances androgen receptor-responsive gene expression depending on androgen level. Proc. Natl. Acad. Sci. USA 2007, 104, 2571-2578. [CrossRef] [PubMed] 
12. Zheng, Y.; Chen, W.L.; Ma, W.L.; Chang, C.; Ou, J.H. Enhancement of gene transactivation activity of androgen receptor by hepatitis B virus X protein. Virology 2007, 363, 454-461. [CrossRef] [PubMed]

13. Schweizer, M.T.; Yu, E.Y. AR-Signaling in Human Malignancies: Prostate Cancer and Beyond. Cancers 2017, 9, 7. [CrossRef] [PubMed]

14. Heinlein, C.A.; Chang, C. Androgen receptor (AR) coregulators: An overview. Endocr. Rev. 2002, 23, 175-200. [CrossRef] [PubMed]

15. Bolton, E.C.; So, A.Y.; Chaivorapol, C.; Haqq, C.M.; Li, H.; Yamamoto, K.R. Cell- and gene-specific regulation of primary target genes by the androgen receptor. Genes. Dev. 2007, 21, 2005-2017. [CrossRef] [PubMed]

16. Yoon, G.; Kim, J.Y.; Choi, Y.K.; Won, Y.S.; Lim, I.K. Direct activation of TGF-beta1 transcription by androgen and androgen receptor complex in Huh7 human hepatoma cells and its tumor in nude mice. J. Cell Biochem. 2006, 97, 393-411. [CrossRef] [PubMed]

17. Koch, D.C.; Jang, H.S.; O’Donnell, E.F.; Punj, S.; Kopparapu, P.R.; Bisson, W.H.; Kerkvliet, N.I.; Kolluri, S.K. Anti-androgen flutamide suppresses hepatocellular carcinoma cell proliferation via the aryl hydrocarbon receptor mediated induction of transforming growth factor- $\beta 1$. Oncogene 2015, 34, 6092-6104. [CrossRef] [PubMed]

18. Chen, C.D.; Welsbie, D.S.; Tran, C.; Baek, S.H.; Chen, R.; Vessella, R.; Rosenfeld, M.G.; Sawyers, C.L. Molecular determinants of resistance to antiandrogen therapy. Nat. Med. 2004, 10, 33-39. [CrossRef] [PubMed]

19. Craft, N.; Shostak, Y.; Carey, M.; Sawyers, C.L. A mechanism for hormone-independent prostate cancer through modulation of androgen receptor signaling by the HER-2/neu tyrosine kinase. Nat. Med. 1999, 5, 280-285. [CrossRef] [PubMed]

20. Gioeli, D.; Ficarro, S.B.; Kwiek, J.J.; Aaronson, D.; Hancock, M.; Catling, A.D.; White, F.M.; Christian, R.E.; Settlage, R.E.; Shabanowitz, J.; et al. Androgen receptor phosphorylation. Regulation and identification of the phosphorylation sites. J. Biol. Chem. 2002, 277, 29304-29314. [CrossRef] [PubMed]

21. Okitsu, K.; Kanda, T.; Imazeki, F.; Yonemitsu, Y.; Ray, R.B.; Chang, C.; Yokosuka, O. Involvement of interleukin-6 and androgen receptor signaling in pancreatic cancer. Genes. Cancer 2010, 1, 859-867. [CrossRef] [PubMed]

22. Szafran, A.T.; Stephan, C.; Bolt, M.; Mancini, M.G.; Marcelli, M.; Mancini, M.A. High-Content Screening Identifies Src Family Kinases as Potential Regulators of AR-V7 Expression and Androgen-Independent Cell Growth. Prostate 2017, 77, 82-93. [CrossRef] [PubMed]

23. Kuuranne, T.; Kurkela, M.; Thevis, M.; Schänzer, W.; Finel, M.; Kostiainen, R. Glucuronidation of anabolic androgenic steroids by recombinant human UDP-glucuronosyltransferases. Drug Metab. Dispos. 2003, 31, 1117-1124. [CrossRef] [PubMed]

24. Yang, W.J.; Chang, C.J.; Yeh, S.H.; Lin, W.H.; Wang, S.H.; Tsai, T.F.; Chen, D.S.; Chen, P.J. Hepatitis B virus X protein enhances the transcriptional activity of the androgen receptor through c-Src and glycogen synthase kinase-3beta kinase pathways. Hepatology 2009, 49, 1515-1524. [CrossRef] [PubMed]

25. Kanda, T.; Yokosuka, O. The androgen receptor as an emerging target in hepatocellular carcinoma. J. Hepatocell. Carcinoma 2015, 2, 91-99. [CrossRef] [PubMed]

26. Kanda, T.; Yokosuka, O.; Omata, M. Androgen Receptor and Hepatocellular Carcinoma. J. Gastrointest. Dig. Syst. 2013, S12. [CrossRef]

27. Wu, M.H.; Ma, W.L.; Hsu, C.L.; Chen, Y.L.; Ou, J.H.; Ryan, C.K.; Hung, Y.C.; Yeh, S.; Chang, C. Androgen receptor promotes hepatitis $\mathrm{B}$ virus-induced hepatocarcinogenesis through modulation of hepatitis $\mathrm{B}$ virus RNA transcription. Sci. Transl. Med. 2010, 2, 32ra35. [CrossRef] [PubMed]

28. Ma, W.L.; Lai, H.C.; Yeh, S.; Cai, X.; Chang, C. Androgen receptor roles in hepatocellular carcinoma, fatty liver, cirrhosis and hepatitis. Endocr. Relat. Cancer 2014, 21, R165-R182. [CrossRef] [PubMed]

29. Brand, L.J.; Dehm, S.M. Androgen receptor gene rearrangements: New perspectives on prostate cancer progression. Curr. Drug Targets 2013, 14, 441-449. [CrossRef] [PubMed]

30. Hu, D.G.; Hickey, T.E.; Irvine, C.; Wijayakumara, D.D.; Lu, L.; Tilley, W.D.; Selth, L.A.; Mackenzie, P.I. Identification of androgen receptor splice variant transcripts in breast cancer cell lines and human tissues. Horm. Cancer 2014, 5, 61-71. [CrossRef] [PubMed]

31. Wang, S.H.; Yeh, S.H.; Shiau, C.W.; Chen, K.F.; Lin, W.H.; Tsai, T.F.; Teng, Y.C.; Chen, D.S.; Chen, P.J. Sorafenib Action in Hepatitis B Virus X-Activated Oncogenic Androgen Pathway in Liver through SHP-1. J. Natl. Cancer Inst. 2015, 107, pii: djv190. [CrossRef] [PubMed] 
32. Ma, W.L.; Hsu, C.L.; Yeh, C.C.; Wu, M.H.; Huang, C.K.; Jeng, L.B.; Hung, Y.C.; Lin, T.Y.; Yeh, S.; Chang, C. Hepatic androgen receptor suppresses hepatocellular carcinoma metastasis through modulation of cell migration and anoikis. Hepatology 2012, 56, 176-185. [CrossRef] [PubMed]

33. Xu, J.; Lin, H.; Li, G.; Sun, Y.; Chen, J.; Shi, L.; Cai, X.; Chang, C. The miR-367-3p Increases Sorafenib Chemotherapy Efficacy to Suppress Hepatocellular Carcinoma Metastasis through Altering the Androgen Receptor Signals. EBioMedicine 2016, 12, 55-67. [CrossRef] [PubMed]

34. Shi, L.; Lin, H.; Li, G.; Jin, R.A.; Xu, J.; Sun, Y.; Ma, W.L.; Yeh, S.; Cai, X.; Chang, C. Targeting Androgen Receptor (AR) $\rightarrow$ IL12A Signal Enhances Efficacy of Sorafenib plus NK Cells Immunotherapy to Better Suppress HCC Progression. Mol. Cancer Ther. 2016, 15, 731-742. [CrossRef] [PubMed]

35. Manetti, R.; Parronchi, P.; Giudizi, M.G.; Piccinni, M.P.; Maggi, E.; Trinchieri, G.; Romagnani, S. Natural killer cell stimulatory factor (interleukin 12 [IL-12]) induces T helper type 1 (Th1)-specific immune responses and inhibits the development of IL-4-producing Th cells. J. Exp. Med. 1993, 177, 1199-1204. [CrossRef] [PubMed]

36. Shi, L.; Lin, H.; Li, G.; Sun, Y.; Shen, J.; Xu, J.; Lin, C.; Yeh, S.; Cai, X.; Chang, C. Cisplatin enhances NK cells immunotherapy efficacy to suppress HCC progression via altering the androgen receptor (AR)-ULBP2 signals. Cancer Lett. 2016, 373, 45-56. [CrossRef] [PubMed]

37. Lai, H.C.; Yeh, C.C.; Jeng, L.B.; Huang, S.F.; Liao, P.Y.; Lei, F.J.; Cheng, W.C.; Hsu, C.L.; Cai, X.; Chang, C.; et al. Androgen receptor mitigates postoperative disease progression of hepatocellular carcinoma by suppressing CD90+ populations and cell migration and by promoting anoikis in circulating tumor cells. Oncotarget 2016, 7, 46448-46465. [CrossRef] [PubMed]

38. Jiang, L.; Shan, J.; Shen, J.; Wang, Y.; Yan, P.; Liu, L.; Zhao, W.; Xu, Y.; Zhu, W.; Su, L.; et al. Androgen/androgen receptor axis maintains and promotes cancer cell stemness through direct activation of Nanog transcription in hepatocellular carcinoma. Oncotarget 2016, 7, 36814-36828. [CrossRef] [PubMed]

39. Grimaldi, C.; Bleiberg, H.; Gay, F.; Messner, M.; Rougier, P.; Kok, T.C.; Cirera, L.; Cervantes, A.; De Greve, J.; Paillot, B.; et al. Evaluation of antiandrogen therapy in unresectable hepatocellular carcinoma: Results of a European Organization for Research and Treatment of Cancer multicentric double-blind trial. J. Clin. Oncol. 1998, 16, 411-417. [CrossRef] [PubMed]

40. Groupe d'Etude et de Traitement du Carcinome Hépatocellulaire. Randomized trial of leuprorelin and flutamide in male patients with hepatocellular carcinoma treated with tamoxifen. Hepatology 2004, 40, 1361-1369.

41. Tran, C.; Ouk, S.; Clegg, N.J.; Chen, Y.; Watson, P.A.; Arora, V.; Wongvipat, J.; Smith-Jones, P.M.; Yoo, D.; Kwon, A.; et al. Development of a second-generation antiandrogen for treatment of advanced prostate cancer. Science 2009, 324, 787-790. [CrossRef] [PubMed]

42. Wu, H.; Zhang, L.; Gao, X.; Zhang, X.; Duan, J.; You, L.; Cheng, Y.; Bian, J.; Zhu, Q.; Yang, Y. Combination of sorafenib and enzalutamide as a potential new approach for the treatment of castration-resistant prostate cancer. Cancer Lett. 2017, 385, 108-116. [CrossRef] [PubMed]

43. Oh, S.J.; Erb, H.H.; Hobisch, A.; Santer, F.R.; Culig, Z. Sorafenib decreases proliferation and induces apoptosis of prostate cancer cells by inhibition of the androgen receptor and Akt signaling pathways. Endocr. Relat. Cancer. 2012, 19, 305-319. [CrossRef] [PubMed]

44. Kudo, M. Immune Checkpoint Inhibition in Hepatocellular Carcinoma: Basics and Ongoing Clinical Trials. Oncology 2017, 92 (Suppl. 1), 50-62. [CrossRef] [PubMed]

(C) 2017 by the authors. Licensee MDPI, Basel, Switzerland. This article is an open access article distributed under the terms and conditions of the Creative Commons Attribution (CC BY) license (http:/ / creativecommons.org/licenses/by/4.0/). 